\title{
異形鉄筋のカス压接関する実験研究
}

その1引張試験につんて

正会員 岡 本 㓮”同

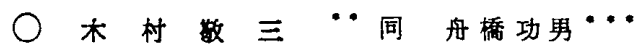

1.はじめに

本報告は社四法人日本代接協会，技術委員会飞机 レて，昭和38年〜41年飞わたり市販品 7 社の異形铁筋

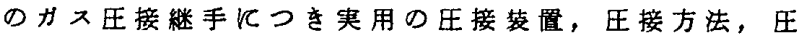
接端面形状にて諸実験をおてをい，との工法に上る継 手奻果(機械的，物理的諸性買)有する加を検討した。

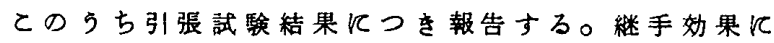

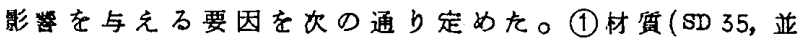
KSD40)(2)径(32 $\left.\frac{11}{m}\right)$ (3)火口形式(4口, 多口)(4)七ット後の

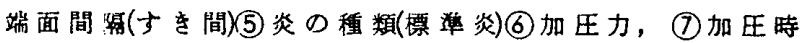
間 (一定)

2. 供試材の加工及び仕上：王接端面はすを間を0 $\sim 0.5 \mathrm{~m} / \mathrm{m}, \quad 1 \sim 3 \mathrm{~m} / \mathrm{m}, 4 \mathrm{~m} / \mathrm{m}$ 以上の 3 種類, ベントンー, ク ラインダー、ベトサンダー仕上とした。

3. 王接作業員:日本王接協会発行の技量就明書(N

A K 3 種)所接者飞施工させ，クロースドバット法を採用。

\section{3. 実験結果の考察}

(a) S D $35, S D 40$ の機的性翼((1) 降伏点 (2)引 張強さ(3)伸ひ)灶コブ付をちば，その奻率壮(1)95 100 . (2) 96〜100\% (3) 59 88\%の籍囲内にあった。

(b) 継手効皮， SD35 コブ付をは96 100\%です， $\operatorname{SD} 40$ コブ付をで沬70〜100\%の值であり，夷用のコ ブ付をて泩継手方法として使用可能てある。

(c)代接部破断と王接機七ット後のす間の関係㤌， す間が $3 \mathrm{~m} / \mathrm{m}$ 以上飞なると圧接部破断の数が增加する 傾向にある。

(d)火口形式，4口，多口的的実用上の問題は ない。

(日) 異形鉄筋江各造メ一カーK上って特性をるつ ており，現段晢飞おいて恃，各特性飞適合した压接方 法に上り実施されるべである。

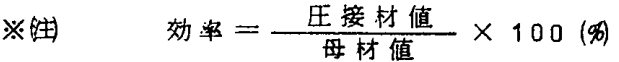

\begin{tabular}{|c|c|c|c|c|c|c|c|c|c|c|c|c|c|c|c|c|c|c|}
\hline \multirow{3}{*}{$\begin{array}{l}\text { 市 } \\
\text { 㬴服 } \\
\text { 試品 } \\
\text { 材 }\end{array}$} & \multirow{3}{*}{ 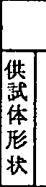 } & \multirow{3}{*}{$\begin{array}{l}\text { 火 } \\
\text { 口 } \\
\text { 形 } \\
\text { 式 }\end{array}$} & \multicolumn{8}{|c|}{$S D \cdot 35 \quad\left(\begin{array}{lll}D & 3 & 2\end{array}\right)$} & \multicolumn{8}{|c|}{$\mathrm{SD} \cdot 40 \quad\left(\begin{array}{lll}\mathrm{D}_{3} & 2 & 2\end{array}\right)$} \\
\hline & & & \multicolumn{2}{|c|}{ 路 伏 点 } & \multicolumn{2}{|c|}{ 引張強度 } & \multicolumn{2}{|c|}{ 伸 ど柬 } & \multicolumn{2}{|c|}{ 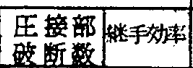 } & \multicolumn{2}{|c|}{ 牛 代 点 } & \multicolumn{2}{|c|}{ 引舆础度 } & \multicolumn{2}{|c|}{ 伸び章 } & \multirow{2}{*}{ 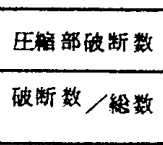 } & \multirow{2}{*}{$\frac{\text { 粎手効事 }}{(\%)}$} \\
\hline & & & 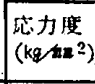 & 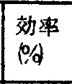 & 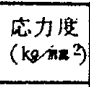 & 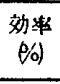 & \begin{tabular}{|c|} 
伸び禹 \\
$\%$
\end{tabular} & 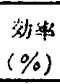 & 伐断篎 & $(\%)$ & 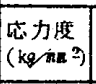 & 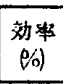 & $\begin{array}{c}\text { 到力度 } \\
\left(\mathrm{kq} / \mathrm{ma}^{2}\right)\end{array}$ & 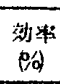 & $\begin{array}{c}\text { 伸び事 } \\
\% \text { \%) }\end{array}$ & $\begin{array}{l}\text { 効好 } \\
0 \% / 2\end{array}$ & & \\
\hline \multirow{4}{*}{ A } & $\exists$ & 4 口 & 38 & 100 & 57 & 99 & 21 & 84 & $1 / 25$ & 96 & 42 & 100 & 64 & 100 & 14 & 68 & $0 / 30$ & 100 \\
\hline & 讨 & 多口 & 38 & 100 & 57 & 98 & 22 & 88 & $1 / 25$ & 96 & 41 & 98 & 64 & 100 & 13 & 61 & $0 / 30$ & 100 \\
\hline & 0.8 & 4 口 & 41 & 98 & 58 & 97 & 21 & 82 & $1 / 10$ & 90 & 45 & 103 & 66 & 98 & 17 & 68 & $6 / 30$ & 80 \\
\hline & 㟢 & 多口 & 42 & 100 & 60 & 100 & 22 & 87 & $8 / 25$ & 68 & 46 & 105 & 68 & 100 & 13 & 61 & $6 / 30$ & 80 \\
\hline \multirow{4}{*}{ B } & 3 & 40 & 41 & 98 & 59 & 96 & 25 & 89 & $5 / 30$ & 83 & 43 & 98 & 62 & 99 & 24 & 72 & $4 / 30$ & 87 \\
\hline & 㣙 & 多口 & 41 & 99 & 61 & 100 & 25 & 82 & $0 / 30$ & 100 & 44 & 99 & 63 & 100 & 23 & 69 & $2 / 30$ & 94 \\
\hline & 08 & $4 \square$ & 41 & 94 & 55 & 83 & 19 & 89 & $12 / 30$ & 60 & 42 & 93 & 56 & 86 & 13 & 66 & $13 / 30$ & 57 \\
\hline & 菻 & 3 & 45 & 103 & 63 & 97 & 18 & 87 & $19 / 30$ & 37 & 46 & 102 & 64 & 98 & 18 & 92 & $16 / 30$ & 47 \\
\hline \multirow{3}{*}{ c } & $\exists$ & 4 口 & 37 & 95 & 60 & 100 & 26 & 86 & $0 / 15$ & 100 & 44 & 102 & 68 & 97 & 23 & 73 & $0 / 15$ & 100 \\
\hline & \begin{tabular}{|l|} 
付 \\
0.8 \\
\end{tabular} & 30 & 39 & 96 & & & & & & & & & & & & & & \\
\hline & 喿 & \begin{tabular}{|l|l|}
4 口 \\
\multicolumn{3}{|l}{ 口 }
\end{tabular} & 39 & 96 & 60 & 100 & 21 & 83 & $1 / 15$ & 93 & 44 & 100 & 68 & 99 & 17 & 75 & $4 / 15$ & 73 \\
\hline \multirow{4}{*}{ D } & $\Rightarrow$ & 40 & 36 & 100 & 57 & 100 & 25 & 88 & $0<1$ & & & & & & & & & \\
\hline & 驸 & 90 & 37 & 102 & 58 & 101 & 20 & 60 & $0 / 30$ & 100 & 40 & 100 & 59 & 100 & 24 & 80 & $0 / 30$ & 100 \\
\hline & 0.8 & $4 \square$ & 39 & 102 & 60 & 102 & $\frac{20}{20}$ & 69 & 030 & 100 & 41 & 101 & 59 & 100 & 21 & 69 & $0 / 30$ & 100 \\
\hline & $\mid \begin{array}{l}P \\
k y\end{array}$ & 多 [1 & 39 & 103 & 60 & 102 & 20 & 89 & $0 / 30$ & 100 & 43 & 102 & 62 & 101 & 19 & 86 & $2 / 30$ & 93 \\
\hline \multirow{4}{*}{$\mathrm{E}$} & $=$ & 44 & 41 & 100 & 54 & $\frac{102}{99}$ & 21 & 90 & 130 & 97 & 43 & 102 & 61 & 101 & 18 & 84 & $0 / 30$ & 100 \\
\hline & z & 多口 & 41 & 100 & 55 & $\frac{99}{109}$ & 28 & 84 & $1 / 30$ & 97 & 48 & 100 & 66 & 96 & 17 & 59 & $9 / 30$ & 70 \\
\hline & 付 & \begin{tabular}{|l|}
44 \\
\end{tabular} & 44 & 100 & 57 & 100 & 25 & 76 & $3 / 30$ & 90 & 49 & 102 & 68 & 100 & 22 & 77 & $3 / 30$ & 90 \\
\hline & 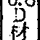 & 多口 & 43 & 99 & 57 & 100 & 18 & 80 & 1,30 & 97 & 52 & 108 & 65 & 96 & 9 & 45 & $23 / 30$ & 23 \\
\hline \multirow{4}{*}{$y$} & ב & 4 & 36 & 101 & 56 & 98 & 18 & 77 & $0 / 30$ & 100 & 51 & 106 & 65 & 95 & 9 & 45 & $20 / 30$ & 33 \\
\hline & fot & 多口 & 36 & \begin{tabular}{|l|}
100 \\
\end{tabular} & $\frac{54}{54}$ & 100 & 28 & 78 & $0 / 30$ & 100 & 43 & 98 & 60 & 100 & 25 & 81 & $1 / 30$ & 97 \\
\hline & $\sqrt{0.8}$ & $41-$ & 38 & 103 & 54 & 100 & 26 & 76 & 0.30 & 100 & 43 & 98 & 60 & 100 & 25 & 82 & $0 \angle 30$ & 100 \\
\hline & $=7$ & 多 & 39 & \begin{tabular}{|l|}
104 \\
104
\end{tabular} & 55 & 99 & 23 & 86 & $9 / 30$ & 70 & 46 & 103 & 58 & 97 & 15 & 47 & $1 8 \longdiv { 1 8 0 }$ & 40 \\
\hline \multirow{5}{*}{ a } & 4 & \begin{tabular}{|l|}
10 \\
40
\end{tabular} & 38 & \begin{tabular}{|l|}
104 \\
100
\end{tabular} & 57 & 102 & 22 & 82 & $17 / 30$ & 43 & 46 & 104 & 62 & 104 & 15 & 48 & $12 / 30$ & 60 \\
\hline & $\exists$ & \begin{tabular}{|lll}
4 & \\
$x$ & 7
\end{tabular} & $\frac{50}{38}$ & $\frac{100}{100}$ & 57 & 100 & 26 & 77 & 0,30 & 100 & 41 & 100 & 60 & 97 & 26 & 82 & $0 / 30$ & 100 \\
\hline & 每 & 品 & 38 & 100 & 57 & 100 & 25 & 75 & $0 / 30$ & 100 & 41 & 100 & 60 & 101 & 24 & 75 & $0 / 30$ & 100 \\
\hline & 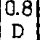 & 4 口 & 41 & 103 & 60 & 102 & 21 & 81 & $1 / 30$ & 97 & 44 & 100 & 63 & 100 & 21 & 84 & $0 / 30$ & 100 \\
\hline & 行 & 多口 & 40 & 100 & 59 & 100 & 20 & 79 & $6 / 30$ & 80 & 42 & 98 & 62 & 100 & 17 & 66 & $10 / 30$ & 67 \\
\hline
\end{tabular}

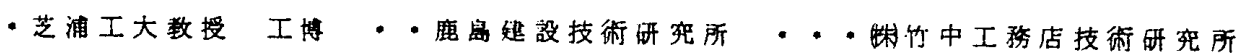

